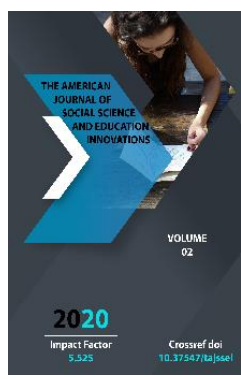

Copyright: Original content from this work may be used under the terms of the creative commons attributes 4.0 licence.

\section{Education In Uzbekistan: Credit-Module System, New Approaches And Views}

\author{
Obidova Farida Ismoilovna \\ Master, Named After Nizami TSPU, Tashkent, Uzbekistan \\ Ergasheva Umida Oripovna \\ Master, Named After Nizami TSPU, Tashkent, Uzbekistan
}

\title{
ABSTRACT
}

This article describes the creation of the credit-module system, its content, forms of training, the expected results of the system, the gradual transition to a credit-module system in Uzbekistan, the conditions and directions.

\section{KEYWORDS}

Credit, module, credit-module training system, ECTS system, independent education, module technology, freedom of educational process, liberalization, curriculum, rating.

\section{INTRODUCTION}

The formation of knowledge and science is directly related to the education system. The effectiveness of the education system is ensured by the level of teachers, the needs of students, the content of textbooks and the infrastructure for the formation of independent learning. This means that the training of advanced personnel, increasing their competitiveness in accordance with the requirements of the labor market, the development of creative thinking professionals are closely linked with the educational process in educational institutions. 
On October 8, 2019, the President signed the Decree "On approval of the Concept of development of the higher education system of the Republic of Uzbekistan until 2030." This important policy document states that "at least 10 higher education institutions in the country will be included in the first 1,000 places in the ranking of internationally recognized organizations (Quacquarelli Symonds World University Rankings, Times Nigher Education or Academic Ranking of World Universities). inclusion in the list and gradual transition of the educational process in higher education institutions to the credit-module system ". It is also expected that by $2030,85 \%$ of all higher education institutions (HEIs) in the country, including 33 higher education institutions in the 2020/2021 academic year, will be transferred to the credit-module system. 'he said. It is natural to ask what the credit-module system is.

The credit-module system is a process of organizing education, which is a model of assessment based on a set of modular technologies of teaching and credit. Carrying it as a whole is a multifaceted and complex systemic process. The credit-module principle focuses on two main issues: ensuring the independent work of students; assessment of students' knowledge on the basis of ratings.

Credit is a unit of study load (time) spent by a student to study and master a subject in a particular field of study or program (course). A credit is a minimum amount of time set by a student's normative document, usually one week, for in-class and independent study. Credit is given to a student after completing the assignments in a particular subject and passing the final exam.

Credit was first introduced in U.S. universities in the 18th and 19th centuries to liberalize the learning process and determine a student's weekly academic workload. In 1869, Charles William Eliot, president of Harvard University and a prominent figure in American education, introduced the concept of the "credit hour." Thus, in 1870-1880, a system of credit hours was introduced. Studying with the credit system and mastering the curriculum allowed students to independently plan the learning process, control its quality, improve educational technology. The introduction of the credit accumulation scale not only gave the student greater freedom, but also provided an opportunity to independently plan the academic process so that he or she could become a competitive professional in his or her chosen field in the future. At the same time, it has led to improvements in the assessment system and educational technology.

\section{The main tasks of the credit-module system} are:

- Modular organization of educational processes;

- Determining the value of one subject, course (credit);

- Assessment of students' knowledge on the basis of rating points;

- Allow students to create their own curricula individually;

- Increase the share of independent learning in the educational process;

- Convenience of educational programs and the possibility of change depending on the demand for specialists in the labor market.

The above is not only to teach on the basis of innovative educational technologies, but also to learn independently from the student, to take a new approach to education, to acquire the necessary and in-depth theoretical knowledge based on the demands of the labor 
market, training to form practical skills. In short, this system is focused on the professional development and maturity of the student. It is aimed at ensuring the lifelong learning of the scientist and the formation of human capital that can meet the requirements of the labor market and modernity.

A module is a part of a curriculum that covers several subjects and courses. It is a set of several disciplines (courses) aimed at developing students' knowledge and skills, the ability to think analytically and logically. In doing so, the teacher organizes the learning process, gives live, video and audio lectures, coordinates and monitors the activities of the student. The student will study the topic independently and complete the assignments.

According to foreign experience, the educational process in the credit-module system consists of 2-4 modules per semester. The disciplines summarized in the module are easily formed from complex theoretical to methodological disciplines and logically complementary. In order to become a specialist, a student needs not only information, but also the ability to process it and put it into practice.

\section{Module-based curricula are developed on the basis of a special scheme and include:}

- Full disclosure of learning objectives and tasks;

- Requirements for the qualifications of the student to be acquired at the beginning and end of the subject (course);

- A summary (syllabus) of each subject included in the module, ie topics of lectures, plans of seminars and practical exercises, assignments for the assessment of independent learning;
- Summary of teaching: methods and tools of teaching; methods and forms of knowledge assessment.

The modular education system uses a rating system to assess students' knowledge, skills and abilities. It assesses all of a student's learning activities, including in-class and out-ofclassroom learning.

\section{MAIN PART}

According to the Bologna Declaration, the credit-module system serves two main functions, emphasizing independent learning:

The first is to ensure the mobility of students and teachers, that is, the free movement (transfer of study or work) from one higher education institution to another without barriers;

Second, the academic load - credit for all academic and research activities of the student in the chosen field of study or specialty is clearly calculated. The sum of the credits shows how much the student has mastered in the chosen program. To create this system, to ensure the integration of all higher education institutions in Europe since the 70s of the last century, to create a single standard of higher education, to establish mobility of students and teachers, recognition of diplomas, student education, efforts will be made to address a number of issues related to the unification of scores for qualifications and skills. As a result of these efforts, the Bologna Declaration was signed in 1999 in Bologna, Italy by representatives of 29 countries. To date, 48 countries are participating in the Bologna process. Russia, Ukraine, Azerbaijan, Moldova, Armenia, Georgia, Kazakhstan and Belarus are among the CIS countries. The training of highly qualified personnel under the Bologna system 
is carried out in two stages. Usually a bachelor's degree of at least three years and a master's degree of 1-2 years.

Today, the model of implementing a credit rating system is widespread. These are the United States Credit System (USCS); European credit system (ECTS); Asia-Pacific Credit System (UCTS); The UK Credit System (CATS). The most common of these models are the U.S. and European models. According to the information, the Ministry of Higher and Secondary Special Education of the country prioritizes the use of the European ECTS system in the introduction of the credit system. Therefore, we consider it appropriate to dwell on its advantages, advantages, advantages and disadvantages.

One of the most important aspects of the Bologna Declaration is the use of a single "credit system" (ECTS) by higher education institutions. A credit or unit of credit is an indicator of the value of any educational activity included in the curriculum. The ECTS system offers great benefits to students in Europe and countries participating in the Bologna process in general. For example, it guarantees that the academic knowledge acquired at the university where the student is studying will be recognized in the higher education institutions of the member countries of the system, that is, in a specific "conversion". At the same time, the system allows members to resume, transfer and terminate their studies at another university.

\section{RESULTS}

The ECTS system also offers a number of benefits to universities. In particular, it ensures the similarity and uniqueness of curricula, which clearly reflect the information about the educational process in a particular field of study and specialization. It also allows for the pre-negotiation of the content of the programs at the higher education institution where the student is admitted and sent in order to achieve recognition of the degree. The student retains responsibility and independence in resolving all issues related to education. In the European education system, courses and the entire educational process are calculated on credit, and in Uzbekistan and other CIS countries on academic hours. Under the ECTS system, the credit structure of each higher education institution, the number of credits for each module, as well as the total amount of credits that must be collected by the student to complete each course and the study period in general independently defines. Unlike the current curriculum, in the credit system, in addition to the compulsory subjects, elective subjects are also included in the student's individual schedule. Students will not be expelled or dropped from course to course. if he cannot collect the credits from which subject (course), he will only retake the examination in that subject. Higher education diplomas are awarded upon completion of the required credits.

\section{DISCUSSION}

As you know, we have limited access to information sources and various international databases. As a result, in higher education, professors focus on finding information, assimilating it, and disseminating it to students after initial processing. That is, teachers were 
merely the subject of receiving and transmitting information. In this case, the student acts as a receiver of information as an object of the educational process, spending most of his time listening to lectures in the classroom. Today, with the acceleration of access to information, the expansion of access to international scientific and technical databases, the acceleration of globalization, the issue of developing students' independent learning has been on the agenda. Curricula of specialties and specialties are supplemented by disciplines that are not related to the requirements of the labor market, mainly in terms of the principle of employment of professors and teachers, the allocation of classroom hours, as well as were formed on the basis of the division of disciplines by mutual consent of the heads of departments. The student was not only allowed to choose subjects and professors, but also to give up boring classes and study in the library. Student truancy was considered a serious loss, with warnings of more than 30 hours per semester and expulsions of more than 74 hours per semester. The student had to sit in the classroom, whether he liked the subject and the teacher, whether the knowledge he was given was left behind.

As noted above, in recent years, our country has taken the first steps to abandon the negative aspects of the traditional education system and to organize work within the requirements of international standards. Currently, 33 higher education institutions of the country are actively working on the transition to a credit-module system. All forces are being mobilized to create this system. An example of this is the fact that the El-Yurt Umidi Foundation regularly organizes seminars for citizens who are engaged in research and teaching activities in foreign universities, who are familiar with the credit-module system. In addition, one of the members of the International Council of Experts under the ElYurt Umidi Foundation has been appointed as an expert advisor to 10 self-financing universities. In order to fully implement these processes, the relevant departments of the higher education institution are being established. The introduction of this creditmodule system in higher education will improve the quality of education, ensure transparency, eliminate corruption, reveal the true knowledge of the student and allow students to study and work independently. creates the ground. Today, the European credit system is practiced in almost all universities in the ancient continent.

The introduction of a credit-module system is an important factor in the collaboration of teachers and students. In modular education, the teacher organizes, directs, advises and checks the process of mastering the listener. The student moves independently towards the directed object. The greatest emphasis is placed on students' independent learning. The importance of independent learning in the learning process will increase, which will lead to an increase in the independence, creative initiative and activity of professionals in the future. In the credit-module system, university students always have the opportunity to get help and advice from teachers and classmates. This strengthens mutual understanding and helps to develop teamwork skills.

The transition to a credit-modular education system will also increase the commitment and demand for university professors. As mentioned above, with a modular learning system, the teacher performs not only informational and supervisory functions, but 
also advisory and coordinating functions. The leading role of the teacher in the pedagogical process is preserved.

\section{CONCLUSION}

The credit system of education increases student exchange. Because loans taken at one university are credited to another, and students can transfer from one university to another without losing credit. It is this system that allows Uzbek students to continue their studies at advanced foreign universities and remove complex bureaucratic barriers. However, it should also be noted that the direct application of any international experience blindly, without taking into account our own values, without a thorough analysis of each of its elements, without scientific it should also be borne in mind that certain adverse events may occur in the future unless they are carried out on a case-by-case basis. This does not mean that this system is fully consistent with our worldview, conditions, and values aimed at raising a harmoniously developed person. Therefore, we need to change the views of teachers and students, who are active elements of the educational process, to instill in them the requirements of this system, to form a unique culture.

We need to feel that we will inevitably lose our place in the competition if we do not train personnel in accordance with the requirements of the labor market. But there is no better way or choice. After all, higher education institutions in all developed countries are following this path and achieving high results. Once our traditional higher education system is not recognized around the world, we are forced to apply advanced standards and systems to higher education institutions. Therefore, the pursuit of innovation, the continuation of the efforts to radically reform the higher education system, is the right decision in all respects.

\section{REFERENCES}

1. Urinov V. ECTS credit-module system in higher education institutions of the Republic of Uzbekistan: Basic concepts and rules. - T.:2020.

2. Jessica Shedd (2003), "The History of the Student Credit Hour". New Directions for Higher Education. 122 (Summer) (122): 5-12.

3. Resolution of The Council and of the Ministers of Education, Meeting within the Council, Official Journal of the European Communities, 1976.

4. Robert Wagenaar, A History of ECTS, 1989-2019. Developing a World Standard for Credit Transfer and Accumulation in Higher Education. International Tuning Academy, 2020. Available at https://www.ruq.nl/research/portal/fil es/111591811/A History of ECTS 1989 2019 PDF.p df

5. European Commission ECTS Guide of 2015. Available at

https://ec.europa.eu/education/ects/us ers-quide/docs/ects-users-quide en.pdf

6. European Cuommission ECTS Guide of 2009. Available at httpsi//ec.europa.eu/education/ects/us ers-quide/docs/vear-2009/ects-usersquide- 2009 en.pdf

7. European Commission ECTS Guide of 2004. Available at https://www.uc.pt/ae3s/pasta docs/ects-users-auidel 70804.pdf 
The American Journal of Social Science and Education Innovations (ISSN - 2689-100x)

Published: December 30, 2020 | Pages: 287-293

Doi: https://doi.org/10.37547/tajssei/Volume02Issue12-50

8. Lutfullayev P. About credit-module training system. -Namangan .: 2019.

9. Internet sources: www.ziyonet.uz

10. www.referat.uz

11. www.arxiv.uz 